УДК 351

E. В. Чорна,

здобувач магістратури кафедри управління охороною здоров' я та публічного

адміністрування, Начіональний університет охорони здоров' я Украӥни імені П. А. Шупика

ORCID ID: 0000-0003-0077-0614

С. П. Кошова,

к. держ. упр., дочент, старший викладач кафедри управління охороною здоров' я та публічного адміністрування, Науіональний університет охорони здоров' я України імені П. А. Шупика

ORCID ID: 0000-0002-7637-4311

DOI: $10.32702 / 2306-6814.2021 .19 .115$

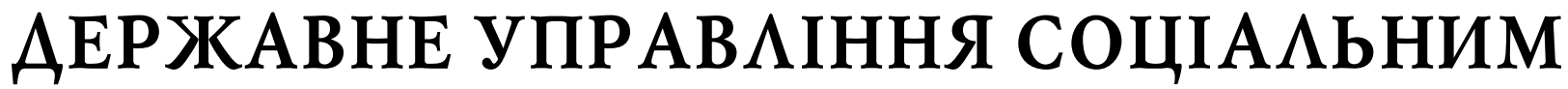 РОЗВИТКОМ ТА ВПРОВААЖЕННЯ МІЖНАРОАНИХ СОЦІААЬНИХ CTAHAАРТIB
}

\author{
Y. Chorna, \\ Master's student of the Department of Healthcare Management and Public Administration, \\ Shupyk National Healthcare University of Ukraine, Kyiv, Ukraine \\ S. Koshova, \\ $\mathrm{PhD}$ in Public Administration, Associate Professor of the Department of Healthcare \\ Management and Public Administration, Shupyk National Healthcare University of Ukraine, Kyiv, Ukraine
}

\section{STATE GOVERNANCE OF SOCIAL DEVELOPMENT AND IMPLEMENTATION OF INTERNATIONAL SOCIAL STANDARDS}

У статті досліджується державне управління соціальним розвитком та впровадження міжнародних соціальних стандартів як один із найважливіших структурних елементів усистемі органів державного управління України у сучасних соціальних відносинах. На сучасному етапі розвитку українського суспільства особливо важливе значення має створення умов для стабільного соціального та гуманітарного розвитку України, соціального та духовного прогресу країни. Зазначене зумовлює важливість засвоєння системи знань про закономірності соціального та гуманітарного розвитку взагалі та особливості процесів у цих важливих сферах суспільного життя в Україні. Проаналізовано теоретичні засади дослідження механізмів державного управління соціальним розвитком та їх практичне значення в Україні. Показано важливість належного теоретичного опрацювання їх сутності, складових та взаємозв 'язків. Проаналізовано сутність категорій "державне управління", "механізм державного управління соціальним розвитком", які імплементують виконавчу влади держави завдяки логічному взаємозв'язку відповідних елементів, процесів та закономірностей. Описано Концепцію державного управління соціальним розвитком. Окреслено комплексний механізм державного управління соціальним розвитком за функціональним призначенням. Визначено класифікацію механізмів державного управління соціальним розвитком за суб'єктами. Відображено типологію механізмів державного управління соціального розвитку за суб'єктами та об'єктами управління. Розглянуто механізм державного управління соціальним розвитком та його практичне значення і наводиться обгрунтування його необхідності. Проаналізовано сучасний стан соціально-економічного розвитку України на основі динаміки соціально-економічних показників України: загальної чисельності населення, включаючи пенсіонерів, ставки заробітної плати та зайнятості тощо. Представлено характерні проблеми, в результаті застосування та дії механізмів державного управління 
соціальним розвитком з урахуванням специфіки функціонування органів публічної влади. Описано процес впровадження міжнародних соціальних стандартів у національне законодавство, та встановлено, що соціальне право ЄСдосягло кращих результатів, ніж право окремих країн у сфері соціального захисту, тому імплементація європейських соціальних стандартів забезпечить належний соціальний розвиток та рівень життя населення в країні.

The article examines the public administration of social development and the implementation of international social standards as one of the most important structural elements in the system of public administration of Ukraine in modern social relations. At the present stage of development of Ukrainian society, it is especially important to create conditions for stable social and humanitarian development of Ukraine, social and spiritual progress of the country. This determines the importance of mastering the system of knowledge about the patterns of social and humanitarian development in general and the peculiarities of the processes in these important areas of public life in Ukraine. Theoretical bases of research of mechanisms of state management of social development and their practical value in Ukraine are analyzed. The importance of proper theoretical elaboration of their essence, components and interrelationships is shown. The essence of the categories "public administration", "mechanism of public administration of social development", which implement the executive power of the state due to the logical relationship of the relevant elements, processes and patterns, is analyzed. The Concept of state management of social development is described. The complex mechanism of state management of social development by functional purpose is outlined. The classification of mechanisms of state management of social development by subjects is determined. The typology of mechanisms of state management of social development by subjects and objects of management is reflected. The mechanism of state management of social development and its practical significance is considered and the substantiation of its necessity is given. The current state of socio-economic development of Ukraine is analyzed on the basis of the dynamics of socio-economic indicators of Ukraine: the total population, including pensioners, wage and employment rates, etc. Characteristic problems as a result of application and action of mechanisms of the state management of social development taking into account specificity of functioning of public authorities are presented. The process of implementation of international social standards into national legislation is described, and it is established that EU social law has achieved better results than the law of individual countries in the field of social protection, so the implementation of European social standards will ensure proper social development and living standards.

Ключові слова: держаВне упраВління, сочіальний розВиток, механізм держаВного упраВління соціальним розВитком, міжнародні сочіальні стандарти, органи держаВної влади.

Key words: public administration, social development, mechanism of state management of social development, international social standards, public authorities.

\section{ПОСТАНОВКА ПРОБАЕМИ}

Оскільки державна служба являється невідокремленим структурним елементом державної влади України, яка фрормує та реалізує політику України на міжнародній арені та відстоює інтереси держави і громадян керуючись нормативно-правовими нормами міжнародного та національного законодавства. Аналіз процесів державного управління соціального розвитку неможливе без дослідження теоретичних засад даних процесів, визначення відповідних категорій державного управління. Серед них важливе місце посідає поняття "державне управління", "механізми державного управління соціальним розвитком" та "міжнародні соціальні стандарти". Без розкриття сутності даних поняття неможливо вирішити проблему практичного застосування та підвищення ефективності державного управління соціальним розвитком та впровадження міжнародних соціальних стандартів і відповідно ефективності усієї системи державного управління.
Наявність досконалих механізмів державного управління соціальним розвитком асекурує цілеспрямоване, скоординоване та раціональне управління соціальними та економічними процесами в країні, належний рівень організаційно-управлінського впливу на розвиток усіх сфрер життя держави, стійку підтримку дій органів державної влади з боку різних верств населення. Оскільки основною метою державного управління соціальним розвитком являється асекурація сприятливих умов для соціально-економічного розвитку та подальшого соціально-економічного зростання в Україні, досягнення соціальної стабільності, підвищення рівня глобальної конкурентоспроможності країни в умовах забезпечення екологічної стабільності. Однак досягти такого розвитку як на національному, так і на локальному рівнях не можливо без застосування обгрунтованих та ефективних механізмів державного управління соціальним розвитком. Позаяк система державного управління соціальним розвитком повинна базуватися на функціонуванні механізму, що передбачає визначення го- 
ловних методів, важелів, інструментів, нормативного та інструктивного забезпечення державного управління, тому актуальним являється розгляд державного управління соціальним розвитком та впровадження міжнародних соціальних стандартів задля реалізації результативної діяльності органів публічної влади.

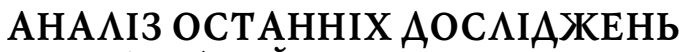 І ПУБ $А$ КАЦІЙ}

Тематику державного управління соціальним розвитком та впровадження міжнародних соціальних стандартів досліджує значна кількість науковців. Зокрема, наукові праці А.В. Овчинніков, Б.І. Сташків, В. Котул, В.А. Рудик, В.М. Мартиненко, В.Я. Малиновський, Г.В. Атаманчук, І.Г. Юник, І.В. Ярмолинська, І. Новосельська, Л.Ю. Малюга, Н.Б. Болотіна, О.В. Сизоненко, О.Д. Лазор, О.М. Вольська, О.М. Рой, О.Я. Лазор, Т.Л. Панкратьєва, Ю.В. Ковбасюк присвячені аналізу деяких аспектів державного управління соціальним розвитком та впровадження міжнародних соціальних стандартів та їх практичне значення в рамках глобалізаційних процесів, які вплинули на соціальний розвиток та становлення державної служби іїї політичну діяльність.

\section{META I ЗАВААННЯ РОБОТИ}

Метою роботи є дослідження державного управління соціальним розвитком та впровадження міжнародних соціальних стандартів задля реалізації результативної діяльності системи органів публічної влади України. Для досягнення мети визначено такі завдання:

1) в загальних рисах проаналізувати державне управління соціальним розвитком України;

2) описати основні аспекти практичного значення механізмів державного управління соціальним розвитком України;

3) дослідити впровадження міжнародних соціальних стандартів для забезпечення реалізації державного управління соціальним розвитком України.

Під час проведення дослідження було використано загальнонаукові й спеціальні методи дослідження, зокрема аналіз і синтез, порівняння, узагальнення, системно-структурний аналіз, політологічний методи.

\section{ВИК ААА ОСНОВНОГО МАТЕРІААУ АОС АІАЖЕННЯ}

Сучасна соціально-економічна ситуація в країні та стратегічний курс розвитку країни вимагають більш зваженого підходу до державного управління, до пошуку раціональних методів реалізації соціального розвитку, з'ясування тих недоліків державної політики, які не дозволяють ефективно здійснювати соціальний розвиток і тим самим підтримувати добробут населення на високому рівні. Важливим моментом вирішення цього завдання $€$ дослідження, яким чином впливає державне управління на соціальний розвиток та впровадження міжнародних соціальних стандартів [1, с. 89].

У вітчизняній та міжнародній науковій думці існує чимало трактувань "державного управління", які являються широко вживаними, однак зміст і структуру його різні науковці та практики висвітлюють по-різному [2, с. 49]. Серед найбільш влучних трактувань "державного управління", на нашу думку, $є:$
1. Діяльність органів державної влади, скеровані на формування кондицій для найповнішої імплементації функцій держави, основних прав і свобод громадян, для узгодження інтересів всіх груп у суспільстві, а також між державою і суспільством, для асекурації суспільного розвитку, завдяки відповідним ресурсам [3, с. 157].

2. Процес регулювання відносин усередині держави за допомогою поділу сфер впливу між основними територіальними рівнями та гілками влади [4, с. 14].

3. Діяльність держави, метою якої являється реалізація управлінського організаційного впливу шляхом застосування повноважень виконавчої влади через організацію виконання законів, виконання управлінських функцій задля комплексного соціально-економічного та культурного розвитку держави, її регіонів, а також асекурація імплементації державної політики у відповідних сорерах суспільного життя, фрормування кондицій для імплементації громадянами їхніх прав і свобод [5, с. 19].

4. Процес здійснення авторитарного врядування через фрормування та реалізацію системи державних органів виконавчої влади на всіх рівнях адміністративно-територіального поділу країни, які застосовують сукупність способів, механізмів і методів владного впливу на суспільство $[6$, с. 21].

5. Вплив держави через діяльність органів державної влади на суспільну та приватну життєдіяльність суспільства, з метою її впорядкування, збереження або перетворення, який спирається наїї владну силу [7, c. 33].

6. Незмінний, організаційний та регулюючий вплив держави на стан і розвиток суспільних процесів, задля досягнення цілей та реалізації функцій держави, відображених у Конституції та законодавчих актах, шляхом імплементації державної політики, виробленої політичною системою та законодавчо закріпленої, через діяльність органів державної влади, наділених відповідною компетенцією [8, с. 22].

Отже, у науковій літературі зустрічається значна чисельність трактування поняття "державного управління", проте немає єдиного узагальненого визначення, де переважна більшість визначень сутності державного управління трактується з позицій конкретних досліджень провідних вчених галузі [9, с. 121].

Дотичне поняття "механізм державного управління" потребує надання трактування, оскільки являється "інструментом" імплементації виконавчої влади держави та представляє собою логічний взаємозв'язок відповідних елементів, процесів та закономірностей, через які суб'єкт державного управління визначає потреби, інтереси та цілі суспільства в управляючих діях, закріплює їх у відповідних управлінських рішеннях та діях, задля практичної імплементації у дійсність, зважаючи на відповідну державну політику [7, с. 11].

Державне управління соціальним розвитком є складовою системи державного управління, яка містить у собі комплекс цілеспрямованих координаційних, мотиваційних, організаційних і контролюючих методів впливу суб'єктів державного управління на соціальний розвиток для реалізації ефективної державної політики, а також санкіонування її інтересів і дій у векторі досягнення стратегічних цілей соціальної держави. У Концепції соціальної держави, яка являється основою для 
реалізації української моделі соціального розвитку держави, в засаді якої містяться механізми державного управління соціальним розвитком (див. рис. 1).

За допомогою механізмів держава через органи публічної влади фрормує соціальну політику, до таких механізмів відносяться політичний, правовий, організаційний, економічний, мотиваційний. Політичний, правовий та мотиваційний механізми відповідають за формування законодавчої бази соціальної політики, а організаційний та економічний механізми фрормують реалізацію законодавчої бази, яка впливає на економічні категорії, тобто на показники рівня та якості життя населення [10].

Отже, комплексний механізм державного управління соціальним розвитком за функціональним призначенням відображений на рисунку 2.

Система управління повинна мати структуру, яка б визначала сталі зв'язки і відносини всередині механіз- ня України щорічно зменшується, тобто майже за тридму, а також основні напрями управлінських впливів, що забезпечувало б його цілісність. Тому обгрунтування структури механізму є одним із ключових завдань розробки його загальної концепції, оскільки як і будь-яка система управління, механізм управління складається з двох підсистем - керуючої (суб'єкт) та керованої (об'єкт) [11, с. 988].

Відповідно до цього, в Україні механізми державного управління за суб'єктами поділяються на наступні, які здійснюються органами управління (див. рис. 3) [9].

Задля того щоб механізм державного управління був ефективним, цілі, на які він направлений, повинні бути гармонізовані, тобто і суб'єкт, і об'єкт управління повинні мати однопорядкові цілі [11, с. 988].

Аналізуючи сучасний стан соціально-економічного розвитку України на основі динаміки соціально-

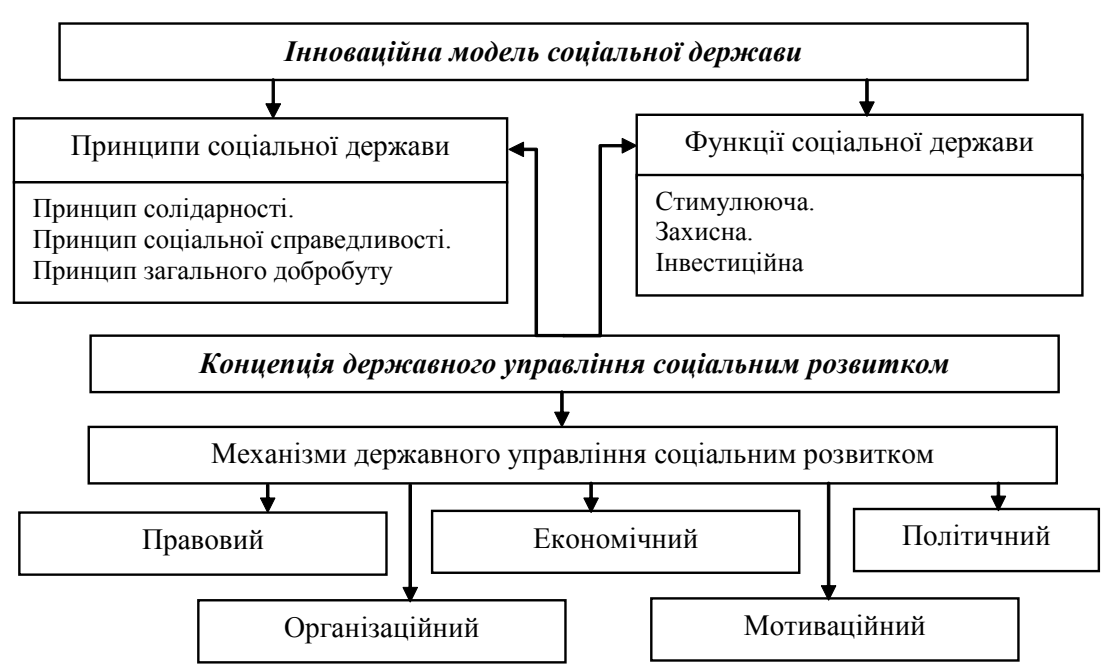

Рис. 1. Концепція державного управління соціальним розвитком

Джерело: сформовано на основі джерела: [10].

економічних показників України: загальної чисельност населення, включаючи пенсіонерів, ставки заробітної плати та зайнятості тощо. За даними таблиці 1, населен-

\begin{tabular}{|l|}
\multicolumn{1}{|c|}{ Мотиваційний } \\
Сукупність командно \\
адміністративних та соціально- \\
економічних стимулів, що \\
спонукають державних службовців \\
до високоефективної роботи \\
\hline
\end{tabular}

\begin{tabular}{|l|}
\hline \multicolumn{1}{|c|}{ Організаційний } \\
Об'єкти, суб'єкти державного \\
управління, їх цілі, завдання, \\
функції, методи управління та \\
організаційні структури, а також \\
результати їх функціонування \\
\hline
\end{tabular}

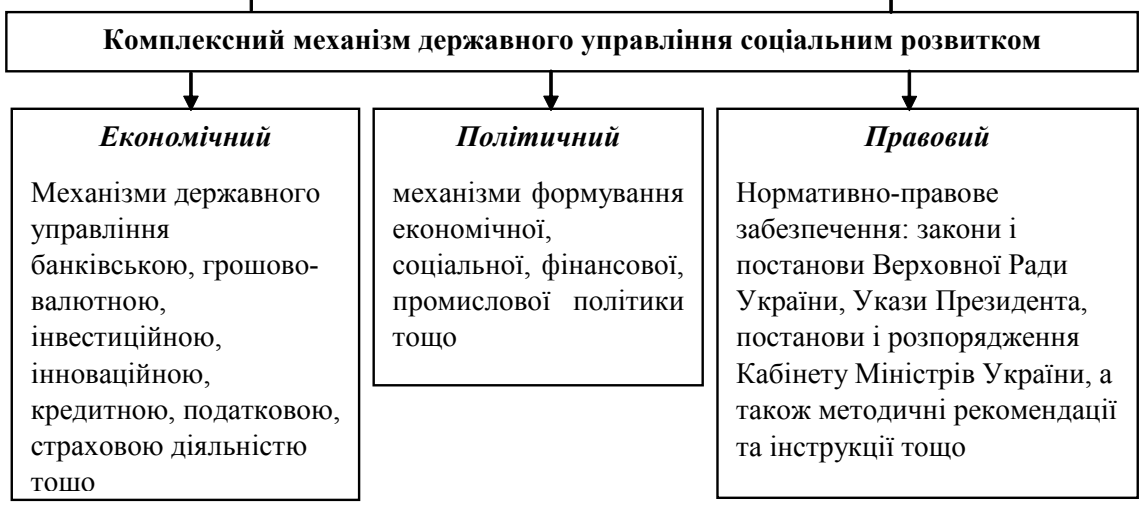

Рис. 2. Комплексний механізм державного управління соціальним розвитком

Джерело: сформовано на основі джерела: [9, с. 121].

\begin{tabular}{|l|l|l|l|}
\hline \multicolumn{3}{|c|}{ Класифікація механізмів державного управління соціального розвитку за } \\
суб'сктами
\end{tabular}

Рис. 3. Класифікація механізмів державного управління соціальним розвитком за суб'єктами

Джерело: сформовано на основі джерела: [9, с. 121]. 
Таблиця 1. Соціально-економічні показники України

\begin{tabular}{|c|c|c|c|c|c|c|c|c|c|}
\hline \multirow[b]{2}{*}{ Роки } & \multirow[b]{2}{*}{$\begin{array}{c}\text { Кількість } \\
\text { населення, } \\
\text { млн осіб }\end{array}$} & \multicolumn{2}{|c|}{$\begin{array}{c}\text { Непрацездатне } \\
\text { населення у віці } \\
15-70\end{array}$} & \multicolumn{2}{|c|}{$\begin{array}{c}\text { Кількість } \\
\text { пенсіонерів }\end{array}$} & \multicolumn{2}{|c|}{$\begin{array}{c}\text { Середньомісячна } \\
\text { заробітна плата }\end{array}$} & \multirow{2}{*}{$\begin{array}{c}\text { Середньо- } \\
\text { місячна } \\
\text { пенсія, } \\
\text { USD }\end{array}$} & \multirow{2}{*}{$\begin{array}{c}\text { Прожитко- } \\
\text { вий } \\
\text { мінімум, } \\
\text { USD }\end{array}$} \\
\hline & & $\begin{array}{l}\text { млн } \\
\text { осіб }\end{array}$ & $\begin{array}{c}\text { \%, від } \\
\text { загальної } \\
\text { к-сті }\end{array}$ & $\begin{array}{l}\text { млн } \\
\text { осіб }\end{array}$ & $\begin{array}{c}\text { \%, від } \\
\text { загальної } \\
\text { к-сті }\end{array}$ & $\begin{array}{c}\text { рередніи } \\
\text { розмір у } \\
\text { проми- } \\
\text { словості, } \\
\text { USD }\end{array}$ & $\begin{array}{l}\text { Виробничий } \\
\text { сектор, USD }\end{array}$ & & \\
\hline 1996 & 51.30 & - & - & 14.49 & 28.24 & 66.70 & 81.00 & 20.49 & - \\
\hline 1997 & 50.82 & - & - & 14.49 & 28.51 & 75.38 & 91.20 & 27.36 & - \\
\hline 1998 & 50.37 & - & - & 14.53 & 28.86 & 44.65 & 54.27 & 15.23 & - \\
\hline 1999 & 49.92 & - & - & 14.52 & 29.09 & 34.12 & 42.18 & 11.64 & - \\
\hline 2000 & 49.43 & 2.66 & 5.37 & 14.53 & 29.39 & 42.32 & 55.57 & 12.68 & 49.68 \\
\hline 2001 & 48.92 & 2.46 & 5.02 & 14.45 & 29.53 & 58.70 & 76.63 & 15.80 & 58.70 \\
\hline 2002 & 48.20 & 2.14 & 4.44 & 14.42 & 29.92 & 70.58 & 90.96 & 22.97 & 64.14 \\
\hline 2003 & 47.83 & 2.01 & 4.20 & 14.38 & 30.06 & \begin{tabular}{|l|}
86.71 \\
\end{tabular} & 110.88 & 25.62 & 64.15 \\
\hline 2004 & 47.47 & 1.91 & 4.02 & 14.35 & 30.22 & 111.14 & 140.12 & 34.34 & 68.23 \\
\hline 2005 & 47.12 & 1.60 & 3.40 & 14.07 & 29.85 & 159.64 & 191.40 & 62.61 & 83.76 \\
\hline 2006 & 46.79 & 1.52 & 3.24 & 14.05 & 30.03 & 206.23 & 240.02 & 80.55 & 93.47 \\
\hline 2007 & 46.51 & 1.42 & 3.05 & 13.94 & 29.97 & 267.52 & 307.72 & 94.73 & 105.35 \\
\hline 2008 & 46.26 & 1.43 & 3.08 & 13.82 & 29.87 & 234.55 & 261.95 & 100.78 & 78.83 \\
\hline 2009 & 46.05 & 1.96 & 4.25 & 13.75 & 29.86 & 238.70 & 265.12 & 117.01 & 87.79 \\
\hline 2010 & 45.87 & 1.71 & 3.74 & 13.72 & 29.91 & 281.22 & 324.05 & 129.70 & 108.14 \\
\hline 2011 & 45.71 & 1.66 & 3.64 & 13.74 & 30.05 & 329.55 & 390.50 & 144.17 & 119.28 \\
\hline 2012 & 45.60 & 1.59 & 3.49 & 13.82 & 30.31 & 378.58 & \begin{tabular}{|l|}
437.88 \\
\end{tabular} & 156.80 & 136.99 \\
\hline 2013 & 45.50 & 1.51 & 3.32 & 13.64 & 29.98 & \begin{tabular}{|l|}
408.48 \\
\end{tabular} & 470.79 & 184.00 & 147.13 \\
\hline 2014 & 43.00 & 1.85 & 4.30 & 13.53 & 31.47 & \begin{tabular}{|l|}
220.69 \\
\end{tabular} & 252.91 & 96.78 & 74.58 \\
\hline 2015 & 42.84 & 1.65 & 3.86 & 12.15 & 28.35 & \begin{tabular}{|l|}
174.79 \\
\end{tabular} & 199.63 & 65.90 & 55.42 \\
\hline 2016 & 42.67 & 1.68 & 3.93 & 12.30 & 28.82 & \begin{tabular}{|l|}
190.62 \\
\end{tabular} & \begin{tabular}{|l|}
217.06 \\
\end{tabular} & 62.50 & 56.78 \\
\hline 2017 & 42.49 & 1.70 & 4.00 & 11.96 & 28.14 & 253.11 & 271.88 & 65.14 & 60.57 \\
\hline 2018 & 42.27 & 1.58 & 3.73 & 11.73 & 27.74 & 320.16 & 347.92 & 89.54 & 66.92 \\
\hline 2019 & 42.03 & 1.49 & 3.54 & & & 443.16 & 497.69 & 105.5 & 85.58 \\
\hline
\end{tabular}

Джерело: сформовано на основі джерела: [12; 13].

цять років загальне скорочення населення перевищило 9 мільйонів. Однак, враховуючи, що офріційний перепис населення в країні востаннє проводився в 2001 році, статистика населення викликає сумніви.

За аналізований період частка пенсіонерів у загальній чисельності населення коливається від 28,24\% до 31,47\%, тобто майже кожна третя людина в країні є пенсіонером. Середньомісячна пенсія в Україні $є$ однією з найменших серед європейських країн і сьогодні наврядчи перевищує 100 доларів США. Крім того, протягом досить тривалого періоду (2000 - 2008 рр.) середньомісячна пенсія була нижчою за мінімальний прожитковий мінімум.

За оцінками "Ukrainian of the Future", кількість працюючих українців найближчим часом можна порівняти з кількістю пенсіонерів. Крім того, за даними тієї ж установи, близько 8 мільйонів українців залучені до еміграції, з них 3 мільйони вже проживають за кордоном із сім'ями. Цей процес являється критичною ситуацією для ринку праці та наповнення бюджету Пенсійного фонду України. Рівень безробіття в Україні коливається від 3,05\% у 2007 році до 5,37\% у 2000 році та має тенденцію до зростання в кризові періоди (2009 р., 2014 р., 2020 р.).

Середньомісячна ставка заробітної плати в промисловості та у виробничому секторі країни має тенденцію до стабільного зростання до 2013 року. Однак спочатку внутрішньополітична, а потім економічна криза 2013-2015 років призвела до різкого знецінення національної валюти і, як наслідок, зменшення середньомісячної заробітної плати в доларах США, і тільки в 2019 році вдалося перевищити середньомісячну заробітну плату в 2013 році (див. табл. 1) [14].
Отже ефективний соціальний розвиток держави можливий тільки за умов трансформації механізмів державного управління соціальним розвитком, проте наявні проблеми, які пов'язані зі слабкою роботою механізмів, не дозволяють забезпечити стабільний соціальний розвиток (див. рис. 4).

Також, одним із проблемних питань у доктрині європейського права є використання юридичної термінології в українських законодавчих актах. Тому варто звернутися насамперед до термінологічного визначення поняття міжнародного соціального стандарту, який являється комплексом норм, який закріплений в міжнародноправових актах, що визначають гідні умови життєдіяльності людей, забезпечують розвиток особи та соціальну захищеність. Ці стандарти мають бути сприйняті законодавством кожної держави шляхом підписання та ратифрікації міжнародних договорів, а надалі повинні бути розвинені та пристосовані до наявних у цій країні умов [16, c. 14].

Стандарти передбачають мінімальні соціальні норми та нормативи, тобто обсяг конкретного виду матеріального забезпечення не може бути нижчим за обсяг, який зафріксований міжнародним актом [17, с. 22]. Дослідники поділяють міжнародно-правові акти, котрі вміщують стандарти соціальних та економічних прав, на всесвітні (універсальні) й регіональні, зокрема європейські [18, с. 276].

Універсальними правовими актами в галузі соціального забезпечення $€$ конвенції Міжнародної організації праці та ООН. ІЇ̈ головний орган - Міжнародна конференція праці, вона займається розробленням і ухваленням нормативних актів - конвенцій та рекомендацій 


\begin{tabular}{|c|c|}
\hline $\begin{array}{l}\text { Механізми державного } \\
\text { управління соціальним } \\
\text { розвитком }\end{array}$ & Проблеми роботи \\
\hline Політичний механізм & $\begin{array}{l}\text { Не реалізована жодна із соціальних функцій держави в } \\
\text { кількісних та якісних параметрах, передбачених законом, } \\
\text { що призводить до недоцільного розподілу бюджетних } \\
\text { коштів і втрати можливостей для практичних позитивних } \\
\text { зрушень у сфері соціального захисту }\end{array}$ \\
\hline Правовий механізм & $\begin{array}{l}\text { Відсутність правового механізму цільового соціального } \\
\text { захисту й допомоги через заплутану та надто } \\
\text { розгалужену систему надання соціальних пільг }\end{array}$ \\
\hline $\begin{array}{l}\text { Організаційний } \\
\text { механізм }\end{array}$ & $\begin{array}{l}\text { Відсутність ефективної системи кадрового забезпечення } \\
\text { соціального розвитку в органах державної влади та } \\
\text { місцевого самоврядування }\end{array}$ \\
\hline Економічний механізм & $\begin{array}{l}\text { Відсутність стимулів з боку держави для приватного } \\
\text { сектора, кошти якого будуть інвестуватися у соціальний } \\
\text { розвиток }\end{array}$ \\
\hline Мотиваційний механізм & $\begin{array}{l}\text { Слабка інвестиційна привабливість галузей соціального } \\
\text { розвитку }\end{array}$ \\
\hline
\end{tabular}

Рис. 4. Проблеми, які взаємопов'язані із дією механізмів державного управління соціальним розвитком

Джерело: сформовано на основі джерела: [15, с. 33].

щодо питань умов праці та соціального забезпечення. Конвенція являє собою міжнародний договір, для взяття зобов'язань за таким документом певна державаучасниця має його ратифікувати. Щодо рекомендацій, то вони містять положення чисто рекомендаційного характеру, їхньою ціллю визначається приведення норм національного законодавства у відповідність до конвенцій, які були ухвалені згаданою організацією та не $\epsilon$ обов'язковими. МОП у своїй діяльності щодо розробки норм соціального забезпечення найбільшу увагу звертала на процес координації національних систем. Таким чином, ця організація заклала фундамент основних соціальних стандартів. Це знайшло своє відображення у визначенні видів допомог та умов їх призначення, встановленні переліку соціальних ризиків за яких особа набуває права на соціальне забезпечення, також були вироблені та нормативно закріплені його мінімальні норми - розміри, тривалість виплат, коло осіб на яке воно поширювалось та ін. Загалом конвенції та рекомендації МОП можна поділити на дві групи: до першої належать ті, предметом вирішення яких $€$ загальні питання, до другої - ті, які регламентують правовий статус окремих суб'єктів.

Вагоме місце у регулюванні стандартів соціального забезпечення займають нормативно-правові акти, ухвалені Генеральною Асамблеєю ООН. Головним внеском $\mathrm{OOH}$ у міжнародно-правове регулювання соціального забезпечення $€$ визначення переліку основних прав людини, які повинні забезпечуватися законодавством будьякої країни. Серед таких документів можна виокремити Загальну декларацію прав людини, Конвенцію про права дитини, Міжнародний пакт про економічні, соціальні та культурні права, Декларацію соціального прогресу і розвитку тощо. У них виражено основні ідеї соціального забезпечення, його принципи: людина як член суспільства має право на соціальний захист, страхування, достатній життєвий рівень, охорону здоров'я.

До регіональних міжнародних актів належать такі, що стосуються права Європейського Союзу. Варто зазначити, що соціальне право ЄС досягло кращих результатів, ніж право окремих країн у сфері соціального захисту. Європейська система соціального забезпечення, основи якої були сорормовані в першій половині $X X$ ст., зараз $€$ найбільш розвинутою у світі [19, с. 314-315]. Рада Європи ухвалила більше 150 актів із питань прав людини, у тому числі й тих, що містять соціальні стандарти.

Основні стандарти в соціальній сорері закріплені в Європейській соціальній хартії (1996р.), Європейському кодексі соціального забезпечення (1990р.), Хартії Європейського співтовариства про основні соціальні права трудящих (1989р.), Хартії основних прав $Є_{\text {вро- }}$ пейського Союзу (2000р.). Міжнародні акти, які пройшли процедуру ратифрікації або ж отримання згоди Верховної Ради на їх обов'язковість, як того вимагає Конституція України, набувають чинності. Значущість цієї обставини полягає передусім у тому, що з моменту набуття чинності угодою норми права, що містяться в ній, набувають загальнообов'язкового характеру [20, с. 17].

Таким чином, трансформація соціального захисту населення України з урахуванням набутого світового досвіду потребує особливого підходу при зміні принципів її побудови, виходячи з ринкових реалій розвитку держави. Крім вищезгаданого, існує проблема часткового виконання чинного міжнародного законодавства у національній правовій системі. Тобто право декларується, але фактично його приписи не виконуються. Якщо безпосередньо вдатися до порівняння національного та міжнародного законодавства з соціального забезпечення, то можна сказати, що законодавство Ук- 
раїни ще не повною мірою відповідає вимогам конвенцій МОП та інших організацій [21, с. 96].

Отже, визначення ефективної системи державного управління соціальним розвитком є одним із найважливіших завдань, оскільки вона має враховувати всю складність зв'язків та специфіку взаємодії між різними об'єктами і суб'єктами управління, узгодженість національних та індивідуальних інтересів, багатоманітність і навіть суперечливість, цілей, досягнення яких покликана забезпечувати механізм державного управління соціальним розвитком.

\section{ВИСНОВКИ 3 ПРОВЕАЕНОГО АОС $\triangle$ IАЖЕНHЯ}

На основі результатів проведеного дослідження було визначено, що в умовах інтенсифікації глобалізаційних процесів розвиток державного управління соціальним розвитком та впровадження міжнародних соціальних стандартів в Україні набуває все більшої актуальності. Формування державного управління соціальним розвитком повинно відбуватись на основі науково обгрунтованих принципів та погоджуватись з інтересами влади, громади та бізнесу. На нашу думку, головними фракторами, що стримують реалізацію державного управління соціальним розвитком та впровадження міжнародних соціальних стандартів в Україні є: ринкові умови господарювання на території України; високий рівень корупції, в тому числі й на рівні державних органів влади; нестабільність політичної ситуації в країні; нестача фрінансових інвестицій; зниження можливості фрормування нових орієнтованих на реалізацію проєктів структур.

У результаті проведеного дослідження державного управління соціальним розвитком та впровадження міжнародних соціальних стандартів в Україні, отримані результати можуть бути використані для вдосконалення системи державного регулювання управління соціальним розвитком в умовах реалізації стратегії країни, що дасть змогу стимулювати інноваційну діяльність та покращити наявну систему управління. Таким чином, оновлення та вдосконалення концептуальних основ реалізації державного управління соціальним розвитком України може стати сучасною парадигмою збереження глобалізаційних тенденцій та механізмів інтеграції національних економік держав до світового співтовариства.

\section{Література:}

1. Овчинніков А. В. Державне податкове регулювання як фактор соціального розвитку України: теоретичний аспект. Економічний вісник Національного гірничого університету. 2018. № 3. С. 88-99. URL: http:// nbuv.gov.ua/UJRN/evngu_2018_3_11 (дата звернення 12.03.2021).

2. Гусейнов Мохлат Йолчу Огли. Поняття механізму державного управління в сфрері соціально-економічного і промислового розвитку. Наукові праці МАУП. 2013. № 4 (39). С. 49-52.

3. Енциклопедія державного управління / ред. кол.: Ю. В. Ковбасюк та ін. Київ: НАДУ, 2011. 747 с.

4. Рой О.М. Система государственного и муниципального управления. СПб.: Питер, 2005. 336 с.
5. Малиновський В.Я. Словник термінів і понять 3 державного управління. 2-ге вид., доп. і перероб. Київ: Центр сприяння інституційному розвитку державної служби, 2005. 252 с.

6. Мартиненко В.М. Демократичне врядування: проблеми теорії та практики. Публічне управління: теорія та практика. 2010. № 1. С. 16-22.

7. Атаманчук Г.В. Теория государственного управлення [текст]. Курс лекций. Москва: Омега-Л, 2005. 584 с.

8. Лазор О.Д., Лазор О.Я., Юник І.Г. Основи державного управління та місцевого самоврядування: навч.метод. посібн. Вид-во 5-те, допов. і перероб. Хмельницький: ТОВ "Поліграфріст-2", 2012. 520 с.

9. Ярмолинська І.В. Поняття та сутність механізмів державного управління у сорері інституційного догляду та виховання дітей в Україні. Інвестиції: практика та досвід. 2018. № 18. С. 119-123.

10. Вольська О.М., Панкратьєва Т.Л. Теоретичні засади державного управління соціальним розвитком сучасної держави. Державне будівництво. 2018. № 2. URL: http:/ /hdl.handle.net/123456789/5667 (дата звернення 12.03.2021).

11. Сизоненко О.В. Теоретичні підходи до формування механізмів державного управління сталим розвитком територій. Молодий вчений. 2018. № 11 (2). С. 987992. URL: http://nbuv.gov.ua/UJRN/molv_2018_11(2)__114 (дата звернення 12.03.2021).

12. Офріційний сайт Державної служби статистики України. URL: http://www.ukrstat.gov.ua/ (дата звернення 12.03.2021).

13. Офіційний сайт Національного банку України. URL: https://bank.gov.ua/ (дата звернення 12.03.2021).

14. Tiurina N.M., Karvatska N.S., Nazarchuk T.V., Baksalova O.M., Ostapchuk O.V. Diagnosis of socioeconomic development of Ukraine. Revista ESPACIOS. 2020. Vol. 41 (№ 27).

15. Вольська О.М. Трансформація механізмів державного управління соціальним розвитком. Публічне управління: теорія та практика. 2013. Вип. 1. С. 30-34. URL: http://nbuv.gov.ua/UJRN/Pubupr_2013_1_7 (дата звернення 12.03.2021).

16. Міжнародні соціальні стандарти: [навч. посіб.] / авт.: А.М. Юшко, Н.М. Швець; за заг. ред. В.В. Жернакова. Харків: Нац. ун-т "Юрид. акад. України ім. Ярослава Мудрого", 2013. 121 с.

17. Сташків Б.І. Гарантії права на соціальне забезпечення [Текст]: навчальне видання. Чернігів: Чернігівський державний інститут права, соціальних технологій та праці, 2011. 100 с.

18.Болотіна Н.Б. Право соціального захисту:становлення і розвиток в Україні / Н.Б. Болотіна. Київ, 2005. 381 с.

19. Рудик В.А. Етапи розвитку міжнародно-правового регулювання соціального забезпечення. Актуальні проблеми юридичної науки на шляху сучасної розбудови держави і суспільства: матеріали Міжнародної науково-практичної конференції (м. Суми, 5-7 червня 2014 р.) / ред. кол.: В.С. Венедіктов, А.М. Куліш, М.М. Бурбика; за ред. В.С. Венедіктова, А.М. Куліша. Суми: СумДУ, 2014. С. 313-317.

20. Малюга Л.Ю. Європейські соціальні стандарти в контексті права на соціальний захист в Україні. Альманах міжнародного права. 2019. Вип. 22. С. 15-25. 
21. Новосельська І., Котул В. Основне значення міжнародних соціальних стандартів у законодавстві України. Підприємництво, господарство і право. 2017. № 3. С. 95-97.

\section{References:}

1. Ovchinnikov, A.V. (2018), "State tax regulation as a factor in the social development of Ukraine: a theoretical aspect", Ekonomichnyi visnyk Natsionalnoho hirnychoho universytetu, vol. 3. pp. 88-99, available at: http://nbuv.gov.ua/UJRN/evngu_2018_3_11 (Accessed 12 March 2021).

2. Huseynov, M. Y. O. (2013), "The concept of the mechanism of public administration in the field of socioeconomic and industrial development", Naukovi pratsi MAUP, vol. 4 (39), pp. 49-52.

3. Kovbasyuk, Yu.V. (2011), Entsyklopediia derzhavnoho upravlinnia, [Encyclopedia of Public Administration], NAPA, Kyiv, Ukraine.

4. Roy, O.M. (2005), Systema hosudarstvennoho y munytsypalnoho upravlenyia, [The system of state and municipal government], St. Petersburg, Russian Federation.

5. Malinovsky, V.Ya. (2005), Slovnyk terminiv i poniat $z$ derzhavnoho upravlinnia, [Dictionary of terms and concepts of public administration], 2nd ed., ext. and processing, Center for Civil Service Institutional Development, Kyiv, Ukraine.

6. Martynenko, V.M. (2010), "Democratic governance: problems of theory and practice", Publichne upravlinnia: teoriia ta praktyka, vol. 1, pp. 16-22.

7. Atamanchuk, G.V. (2005) Teoryia hosudarstvennoho upravlennia, [Theory of public administration], Omega-L, Moscow, Russian Federation.

8. Lazor, O.D., Lazor, O.Ya. and Yunik, I.G. (2012) Osnovy derzhavnoho upravlinnia ta mistsevoho samovriaduvannia, [Fundamentals of public administration and local government], LLC "Polygraphist-2", Khmelnytsky, Ukraine.

9. Yarmolynska, I. (2018), "Concept and essence of mechanisms of public administration in the field of institutional care and education of children in Ukraine", Investytsiyi: praktyka ta dosvid, vol. 18, pp. 119-123.

10. Volskaya, O.M., Pankratieva, T.L. (2018), "Theoretical principles of public administration of social development of the modern state", Derzhavne budivnytstvo, [Online], vol. 2, available at: http://hdl.handle.net / 123456789/5667 (Accessed 12 March 2021).

11. Sizonenko, O.V. (2018), "Theoretical approaches to the formation of mechanisms of public administration for sustainable development of territories", Molodyi vchenyi, [Online], vol. 11 (2), pp. 987-992, available at: http://nbuv.gov.ua/UJRN/molv_2018_11(2)__114 (Accessed 12 March 2021).

12. The official site of the State Statistics Service of Ukraine, available at: http://www.ukrstat.gov.ua / (Accessed 12 March 2021).

13. The official site of the National Bank of Ukraine (2021), available at: https://bank.gov.ua/ (Accessed 12 March 2021).

14. Tiurina, N.M., Karvatska, N.S., Nazarchuk, T.V., Baksalova, O.M. and Ostapchuk, O.V. (2020), "Diagnosis of socio-economic development of Ukraine", Revista ESPACIOS, Vol. 41 (№ 27).

15. Volskaya, O.M. (2013), "Transformation of mechanisms of state management of social development", Publichne upravlinnia: teoriia ta praktyka, [Online], vol. 1, pp. 30-34, available at: http://nbuv.gov.ua/UJRN/ Pubupr_2013_1_7 (Accessed 12 March 2021).

16. Yushko, A.M., Shvets, N.M. and Zhernakova, V.V. (2013), Mizhnarodni sotsialni standarty, [International social standards], National University "Yaroslav the Wise Law Academy of Ukraine", Kharkiv, Ukraine.

17. Stashkiv, B.I. (2011), Harantii prava na sotsialne zabezpechennia, [Guarantees of the right to social security], Chernihiv State Institute of Law, Social Technologies and Labor, Chernihiv, Ukraine.

18. Bolotina, N.B. (2005), Pravo sotsialnoho zakhystu: stanovlennia i rozvytok $v$ Ukraini, [The right of social protection: formation and development in Ukraine], Kyiv, Ukraine.

19. Rudik, V.A. (2014), "Stages of development of international legal regulation of social security", Aktualni problemy yurydychnoi nauky na shliakhu suchasnoi rozbudovy derzhavy i suspilstva: materialy Mizhnarodnoi naukovo-praktychnoi konferentsii (m. Sumy, 5-7 chervnia 2014 r.), [Actual problems of legal science on the way of modern development of the state and society: materials of the International scientificpractical conference] A.M. Sumy State University, Sumy, Ukraine, June 5-7, pp. 313-317.

20. Malyuga, L. Yu. (2019), "European social standards in the context of the right to social protection in Ukraine", Almanakh mizhnarodnoho prava, vol. 22, pp. 15-25.

21. Novoselska, I. and Kotul, V. (2017), "The main importance of international social standards in the legislation of Ukraine", Pidpryiemnytstvo, hospodarstvo i pravo, vol. 3, pp. 95-97.

Стаття надійшла до редакиї 05.08.2021 p.

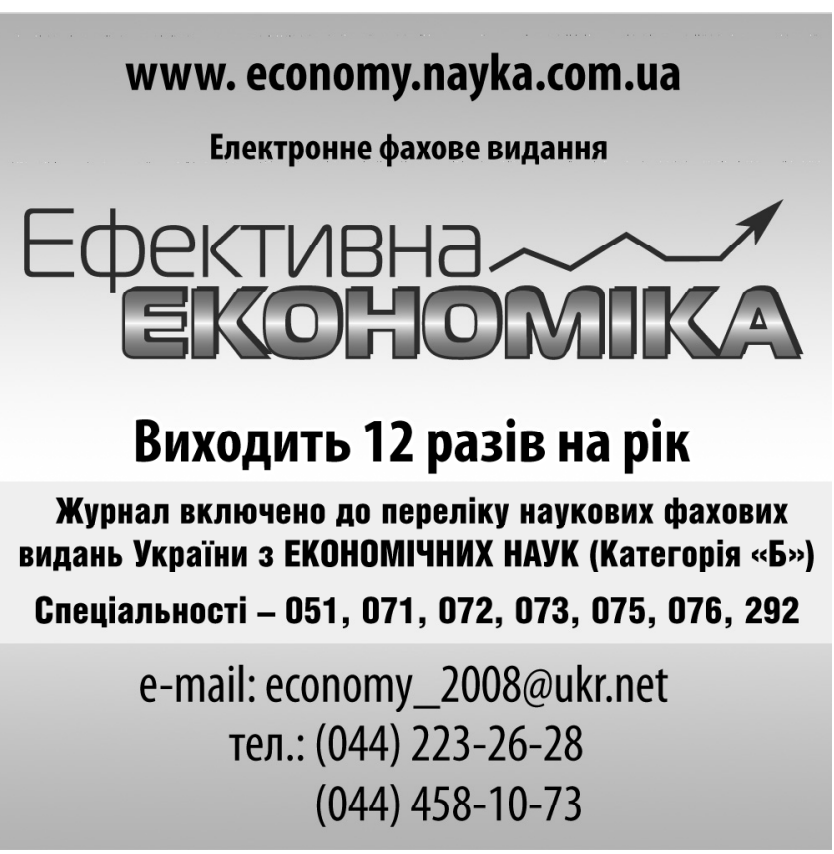

